\title{
THE LESSONS FROM THE EURO EXPERIENCE
}

\section{Richard Griffiths ${ }^{1}$}

Twenty years ago, amid a great fanfare of enthusiasm, the Treaty of Maastricht created the European union and inaugurated the process for creating a single European currency for most of the then members (except the UK and Sweden, and later Denmark, that were given a temporary exemption) and all future members. Twenty years later, the anniversary of the treaty passed almost unnoticed (EUROPEAN POLICY CENTER, 2012). On that day, however, the impact of the treaty was never far from the headlines, as had also been the case for almost every day over the previous months. The Lehman brothers bankruptcy in September 2008 not only triggered a financial crisis that threatened to engulf the world, but it set in motion a series of shocks that have since reverberated through the Euro-area. It is fair to say that the crisismanagement has not been an example of stream-lined efficiency, and there are lessons to be learned from that experience.

However, the development of the Euro, and the crisis that has subsequently engulfed it, holds lessons in another direction. The European Union has long been held as a model, or an inspiration, for other experiments in regional cooperation and integration, including Mercosul, ASEAN and SADC. The model embodied a sequence of steps leading to 'ever closer union' that moved from a free trade area through a customs union and a single market and culminated in economic and monetary union. With the signing and implementation of the Treaty of Maastricht, the European Union had

\footnotetext{
${ }^{1}$ Professor of Social and Economic History, Leiden University. (r.t.griffiths@hum.leidenuniv.nl)
} 
embarked on the penultimate step in this progression. But only half of it - a monetary union without a fiscal union. The Euro-crisis has now called that achievement into question and, in the process, undermined the authority of those espousing a European route towards closer integration, both for themselves as well as for other nations. As a convinced federalist, myself, I would not recommend abandoning the European example altogether, but if there is a lesson to be learned from this sorry episode, it is this: "if you are going to do it, do not do it this way".

This article examines the European experience with economic and monetary union from three perspectives - the design, the implementation and the management of the euro - before exploring the implications of the current crisis.

\section{The Design}

The decision to embark on the path towards economic and monetary union was taken after a period of remarkable exchange-rate stability in Western Europe. Introduced in 1979, it built on the experience of the exchange-rate mechanism (ERM) which had tied members exchange rates to a band of 2.25 per cent either side of par (except for Italy which was given a band of 6 per cent) and which had enhanced central bank cooperation to maintain the parities. Its introduction, however, had coincided with the second oil crisis and the system lurched from one crisis to the other, each being resolved by a devaluation or revaluation within the system to maintain the illusion that it remained intact. It was similar to a 'crawling peg' arrangement, but to dignify it with this description would be totally to exaggerate the orderliness of its workings and to forget the whiff of fear surrounding its operation. Within the space of three and a half years, a gap on almost 30 per cent had opened up in the exchange rates of the strongest (German DM) and weakest (Italian Lire) currencies. But then French economic policy converged with the rest, and a calm descended on the markets. The pervious turmoil was conveniently forgotten (JORDANWAGNER, 1994). Little now seemed to disturb the serenity of European exchange rates and toward the end of the decade several non-members joined the system - Spain in June 1989, the UK in October 1990 and Portugal in April 1992. It was against this backdrop that in February 1992 that the Treaty of Maastricht was signed (ISSING, 2008). 


\section{Richard Griffiths}

The design for economic and monetary union was based on five requirements that had to be met before being accepted into the single currency. First, countries had to have maintained stable exchange rates within the ERM for two years preceding membership. There then followed two fiscal targets the stipulation that the annual government deficit should not exceed 3 per cent and that the level of sovereign debt should be no higher than 60 per cent. Presumably assuming that these requirements were met, there followed two further targets (or consequences) for the rates of inflation and for the cost of long-term borrowing. But these were given a further tweak in the direction of monetary prudence by expressing the targets not in terms of the average for the group, but in terms of the three lowest in the group, regardless of their relative size or importance. Thus inflation was not to exceed this target by more than 1.5 percentage points and long-term interest rates were not to be more than 2 percentage points higher. Generally, these requirements were perceived at the time to be deflationary and this was interpreted as a concession to German demands as the price for surrendering its own domestic currency, which had been exceptionally successful in this respect. And what was good for Germany was presumably good for the rest of us as well (GARRETT, 1993).

Although the design has the virtue of simplicity, there are several curious deficiencies. For a start, the target for the deficit is absolute and only in one direction. It offers no opportunity for offsetting better performances (lower deficits or even surpluses) against an overshoot. If a deficit comes as a result of a recession, there is still an obligation to impose a deflationary budget. There is no scope at all for the kind of deficit financing engaged upon by the US in the shadow of the recession following the Lehman crisis and staying within the rules. Secondly, there is an inconsistency between tolerating a government deficit, albeit 3 per cent, and the objective of holding down the level of external sovereign debt. The only way to avoid steadily accumulating a relatively greater debt is either to grow faster than 3 per cent that is added to the debt burden (BUITER; CORSETTI; ROUBINI, 1993). Growing consistently, or even sporadically, faster than 3 per cent per annum is something that the more advanced European economies have struggled to do since the first oil crisis of 1973. On the other hand, growth 'convergence' for the less advanced economies was almost a religion among European economists, as they utilized untapped 
productivity resources and invested the convergence or cohesion funds transferred to them from the EU budget. Unfortunately, the recipe for growth usually entailed a trade-off in terms of higher inflation (FINGLETON, 1999; LEONARDI, 1995). This, in its turn would create a further problem. Locked first into fixed exchange rates, which precluded any currency depreciation, and later locked into a single currency and, furthermore, deprived of domestic monetary instruments, there were few options for dealing with the cumulative inflationary results. Finally, the interest rate target is an implied derivative from achieving the prescribed budget discipline and seem to be left to the mercy of the markets. This is eminently sensible, if the market is assumed to operate rationally and predictably. If it does not, however, governments are left with pitifully few short-term policy measures to alleviate the situation, and so too were the officials of the European Union. The stance of the monetary authorities was to be that there would be no 'bail-out' of economies in difficulties and therefore there was no provision of funds to cover just such an eventuality.

\section{Implementation}

The Maastricht treaty envisaged three steps whereby the new European currency would be created. In the first phase, capital controls would be removed and inter-bank cooperation would pave the way for the creation of a more central monetary authority. The second stage began with the creation of a European Monetary Institute and the five criteria agreed in Maastricht were enshrined in a Stability and Growth Pact, which was to be monitored by the European Commission. At the end of this stage, exchange rates would be locked together and the European Central Bank would be established. At this stage the euro was introduced as a means of transactions, but the launch of the currency into circulation would wait for four years (ISSING, 2008). That moment took place on $1^{\text {st }}$ January 2002. I was in Rome that day and still remember how, at the end of the day, I examined the loose change in my pocket to discover also coins minted in Germany, Ireland and the Netherlands. I should add that the novelty soon wore off. By then, however, things were already going badly wrong.

In May 1998 eleven members of the EU were declared to have met the conditions for euro membership and became the first wave to adopt the new 


\section{Richard Griffiths}

currency. Two other members, namely Denmark and the UK, had acquired optout clauses. This left only Greece and Sweden as members deemed ineligible, and Greece was admitted into the new currency in January 2001. For the record, all subsequent members of the European Union assumed the obligation to join the euro area, when conditions had been met. Slovenia did so in 2007, Cyprus and Malta joined the following year, Slovakia acceded the year after that and, finally in 2011 Estonia became a member.

But let us return to those heady halcyon days of Europhoria as countries lined up to join the new currency area. One criteria was that they should have a government debt ratio of no more than 60 per cent of GDP, but should it be higher at the moment of entry, that it should be diminishing at a "satisfactory pace". If we look at the statistics that policy-makers had before them at the time, in the two years before joining, three countries - Belgium, Italy and Greece - had debt ratios already towering above 100 per cent of GDP. Although they showed some decline this was at a rate that would still leave them far outside the target range two decades later. Greece too, had a debt ratio hovering around 100 per cent. Five other members - Austria, Germany, the Netherlands and Portugal and Spain - had debt ratios between 60 and 70 per cent.

Table 1: Government Debt:GDP Ratio (\%)

\begin{tabular}{|c|c|c|c|c|c|c|c|c|c|c|c|}
\hline \multicolumn{2}{|c|}{ Austria } & \multicolumn{2}{c|}{ Belgium } & \multicolumn{2}{c|}{ Finland } & \multicolumn{2}{c|}{ France } & \multicolumn{2}{c|}{ Germany } & \multicolumn{2}{c|}{ Ireland } \\
\hline 1997 & 1998 & 1997 & 1998 & 1997 & 1998 & 1997 & 1998 & 1997 & 1998 & 1997 & 1998 \\
\hline 66.1 & 65.6 & 124.7 & 121.3 & 59.0 & 57.3 & 57.3 & 58.2 & 61.7 & 61.4 & 65.8 & 59.2 \\
\hline \multicolumn{2}{|c|}{ Italy } & \multicolumn{2}{|c|}{ Luxembourg } & \multicolumn{2}{|c|}{ Netherlands } & \multicolumn{2}{c|}{ Portugal } & \multicolumn{2}{c|}{ Spain } & \multicolumn{2}{c|}{ Greece } \\
\hline 1997 & 1998 & 1997 & 1998 & 1997 & 1998 & 1997 & 1998 & 1997 & 1998 & 2000 & 2001 \\
\hline 123.2 & $\mathbf{1 2 1 . 9}$ & 6.7 & 6.9 & 73.4 & 71.5 & $\mathbf{6 2 . 5}$ & $\mathbf{6 0 . 8}$ & $\mathbf{6 8 . 1}$ & $\mathbf{6 6 . 5}$ & $\mathbf{1 0 2 . 8}$ & $\mathbf{9 9 . 7}$ \\
\hline
\end{tabular}

Source: European Commission, European Economy. Statistical Annex 1998 and 2001

If the Maastricht treaty had been taken seriously, the introduction of the Euro in 1999 should have taken place with seven fewer members than it did, and Greece should not have been allowed to join two years later. This, of course, is where politics enters the frame. A major step forward on the road to integration without four of the six founding members of the European Union was plainly unthinkable. Equally a monetary union comprising only Finland, France, Ireland and Luxembourg would have made no economic sense 
whatsoever. So, for the first time, and not for the last, the details of an agreement were pushed aside to make way for political expediency. And, having admitted Belgium and Italy with excessive sovereign debt ratios, the EU was scarcely in a position to extend the courtesy to Greece whose debt ratio appeared less bad than either of these. Policy-makers work with figures that they have to hand, but these figures are often revised afterwards either because the data itself is updated or because definitions have shifted. For debt ratios these revisions over time have been favourable, and would have allowed Portugal to qualify for euro-membership on this criteria. For Greece, however, the situation was slightly worse(EUROPEAN COMISSION. European Economy, Statistical Annex, 2011).

Table 2: Net government borrowing (-) or lending (+) as \% gdp

\begin{tabular}{|l|l|l|l|l|l|l|l|l|l|l|l|}
\hline \multicolumn{2}{|c|}{ Austria } & \multicolumn{2}{c|}{ Belgium } & \multicolumn{2}{c|}{ Finland } & \multicolumn{2}{c|}{ France } & \multicolumn{2}{c|}{ Germany } & \multicolumn{2}{c|}{ Ireland } \\
\hline 1997 & 1998 & 1997 & 1998 & 1997 & 1998 & 1997 & 1998 & 1997 & 1998 & 1997 & 1998 \\
\hline-2.8 & -2.6 & -2.6 & -2.3 & -1.4 & -0.2 & -3.1 & -3.0 & -3.0 & -2.6 & +0.6 & +1.2 \\
\hline \multicolumn{3}{|c|}{ Italy } & Luxembourg & \multicolumn{2}{|c|}{ Netherlands } & \multicolumn{2}{c|}{ Portugal } & \multicolumn{3}{c|}{ Spain } & \multicolumn{3}{c|}{ Greece } \\
\hline 1997 & 1998 & 1997 & 1998 & 1997 & 1998 & 1997 & 1998 & 1997 & 1998 & 2000 & 2001 \\
\hline-3.0 & -3.7 & +1.6 & +1.0 & -2.1 & -2.9 & -2.7 & -2.4 & -2.9 & -2.4 & -2.7 & -3.1 \\
\hline
\end{tabular}

Source: European Commission, European Economy. Statistical Annex 1998 and 2001

A second Maastricht criteria was that current government deficits should not exceed 3 per cent of GDP. At first sight, the record on this score was remarkably good but the results conceal a great deal of statistical and definitional creativity. Pension funds were creamed and capital assets sold and included under current revenue; parts of government debt were conveniently parked out of sight and GDP figures were massaged upwards, by as much as 1020 per cent (BOS, 2008. FN 15). The impact of changes in methods and definitions in the Netherlands in 2001, for example, to raised its GDP by 4.5 per cent and reduced its debt ratio from 52.95 to 50.7per cent (CBS, Press Release, 1.6.2005). There was plenty of room for further revisions, if efforts were taken to include the 'black economy' in official estimates as Italy did in 1987, thereby, in one leap, overtaking the UK as the world's fifth largest economy (SIESTO, 1987). Even so, Italy and Greece still failed to meet the Maastricht criteria on this point, but were still admitted. The reason was simple. If one was going to ignore a mountain of debt, who was going to quibble over a couple of decimal 


\section{Richard Griffiths}

points? In this particular case, historical revision had not been too kind to Portugal, Spain and Greece, all of which now have fallen above the three percent range and therefore the official qualification threshold.

\section{Management}

Once the Euro had been introduced, it was for the European Central Bank and the ministers of finance of the Eurozone to manage the new currency. The backbone for monetary discipline was the so-called Stability and Growth Pact, that took over in their entirety all the Maastricht criteria. One of these was that budget deficits should be no higher than 3 per cent of GDP. This was first seriously challenged in 2001-2 when a temporary recession led to a surge in budget deficits and threatened to push France, Germany, Italy and Portugal over the threshold. It was ironic that this crisis should embroil Germany since it had been largely responsible for insisting on a strict and restrictive rule in the first place. Had the rule contained some counter-cyclical provisions such a development would never have caused a problem but that was not the case. Indeed breaching the rules could invoke sanctions in the form of fines equivalent to $0.5 \%$ of GDP. But these sanctions were not automatic.

Instead of accepting the discipline of their own rules, France and Germany together began a campaign for 'easing' them. As a result of their combined pressure, a recommendation by the Commission that the two countries take immediate measures to rectify the position was overruled by the finance ministers at their meeting in November 2003 (COLLINGON, 2004). In 2005 the ministers, against the misgivings of the ECB, relaxed the rules themselves in a way that allowed the ministers to take a longer-term view of budget perspectives and which permitted countries with a debt ration below 60 per cent a budget deficit of 1 per cent of gdp, but which held countries with a deficit of over 100 per cent to achieving a balanced budget or even generating a surplus (FISCHER; JONGUN; LARCH, 2006). Significantly, nothing was done to strengthen enforcement mechanisms and the new regime was repeatedly flouted by countries as Austria, Greece, Italy and Portugal. The reason was simple. Once the rules had been bent in favour of the strong, they lost the moral authority to reimpose them on the weak even if they had the inclination to do so. 
Table 3: Government Debt:GDP Ratio (\%)

\begin{tabular}{|l|l|l|l|l|l|l|l|l|l|l|}
\hline & 99 & 00 & 01 & 02 & 03 & 04 & 05 & 06 & 07 & 08 \\
\hline Austria & -2.7 & -2.9 & -4.3 & -2.9 & -3.0 & -3.4 & -5.9 & -4.1 & -3.1 & -3.5 \\
\hline Belgium & -0.6 & 0.0 & +0.4 & -0.1 & -0.1 & -0.3 & -2.7 & -0.1 & -0.3 & -1.3 \\
\hline Finland & +1.6 & +6.8 & +5.0 & +4.0 & +2.4 & +2.3 & +2.7 & +4.0 & +5.2 & +4.2 \\
\hline France & -1.8 & -1.5 & -1.5 & $\mathbf{- 3 . 1}$ & -4.1 & $\mathbf{- 3 . 6}$ & -2.9 & -2.4 & -2.7 & $\mathbf{- 3 . 3}$ \\
\hline Germany & -1.5 & 1.3 & -2.8 & $\mathbf{- 3 . 7}$ & $\mathbf{- 4 . 0}$ & $\mathbf{- 3 . 8}$ & $\mathbf{- 3 . 3}$ & -1.6 & +0.3 & +0.1 \\
\hline Greece & $\mathbf{- 3 . 1}$ & $\mathbf{- 3 . 7}$ & $-\mathbf{4 . 5}$ & $\mathbf{- 4 . 8}$ & $\mathbf{- 5 . 6}$ & $\mathbf{- 7 . 5}$ & $\mathbf{- 5 . 2}$ & $\mathbf{- 5 . 7}$ & -6.4 & $\mathbf{- 9 . 8}$ \\
\hline Ireland & +2.7 & +4.7 & +0.9 & -0.4 & +0.4 & +1.4 & +1.6 & +2.9 & +0.1 & -7.3 \\
\hline Italy & -1.7 & -0.8 & $\mathbf{- 3 . 1}$ & -2.9 & $\mathbf{- 3 . 5}$ & $\mathbf{- 3 . 5}$ & -4.3 & $\mathbf{- 3 . 4}$ & -1.5 & -2.7 \\
\hline Luxembourg & +3.4 & +6.0 & +6.1 & +2.1 & +0.5 & -1.1 & 0.0 & +1.4 & +3.7 & +3.0 \\
\hline Netherlands & +0.4 & +2.0 & -0.2 & -2.1 & $\mathbf{- 3 . 1}$ & -1.7 & -0.3 & +0.5 & +0.2 & +0.6 \\
\hline Portugal & -2.7 & -2.9 & -4.3 & -2.9 & -3.0 & -3.4 & $\mathbf{- 5 . 9}$ & -4.1 & $\mathbf{- 3 . 1}$ & $\mathbf{- 3 . 5}$ \\
\hline Spain & -1.4 & -1.0 & -0.6 & -0.5 & -0.2 & -0.3 & +1.0 & +2.0 & +1.9 & -4.2 \\
\hline
\end{tabular}

Source: European Commission, European Economy. Statistical Annex 2011

The 'result' of fiscal prudence should have revealed itself in two 'market' mechanisms -relatively low government borrowing costs and relatively low inflation rates. Indeed both 'effects' were apparent. One almost immediate impact was a sharp reduction in the range of interest rates governments had to pay for long-term borrowing, which was in sharp contrast to the period leading up to the adoption of the Euro (EHRMANN et al, 2011). What is slightly more disturbing is why this should have been so. In economic theory markets function properly when there is transparency, shared knowledge, low transaction costs and economically rational actors. Government debt should be one of the more predictable markets. Nonetheless the rate of interest paid on the debt of a poor, debt-burdened economy renowned for its fiscal laxity (like Greece) and on that of a rich, relatively debt-light economy known for its fiscal rectitude (like Germany) was virtually identical. Few, however, remarked on the irrationality and unpredictably of capital markets. One effect was to allow countries to refinance their debts relatively cheaply, and thus removing the market penalty on persistent deficits at a time when the political sanction had also been abandoned. For the poorer economies, high government debt levels were refinanced far below those prevailing in previous decades. There was little incentive to trim excessive deficits back to the 60 percent threshold and both Germany and France (not to mention Austria, Belgium, Greece, Italy and later Portugal) allowed themselves the luxury of higher levels of sovereign debt that than stipulated in the Stability and Growth Pact. 


\section{Richard Griffiths}

Table 4: Government Debt: GDP Ratio (\%)

\begin{tabular}{|l|l|l|l|l|l|l|l|l|l|l|}
\hline & 99 & 00 & 01 & 02 & 03 & 04 & 05 & 06 & 07 & 08 \\
\hline Austria & 67.2 & 66.5 & 67.1 & 66.5 & 65.5 & 64.8 & 63.9 & 62.1 & 60.7 & 63.8 \\
\hline Belgium & 113.7 & 107.9 & 106.6 & 103.5 & 98.5 & 94.2 & 92.1 & 88.1 & 84.2 & 89.6 \\
\hline Finland & 45.7 & 43.8 & 42.5 & 41.5 & 44.5 & 44.4 & 41.7 & 39.7 & 35.2 & 34.1 \\
\hline France & 58.8 & 57.3 & 56.9 & 58.8 & 62.9 & 64.9 & 66.6 & 63.7 & 63.9 & 67.7 \\
\hline Germany & 60.9 & 59.7 & 58.8 & 60.4 & 63.9 & 65.8 & 68.0 & 67.6 & 64.9 & 66.3 \\
\hline Greece & 94.0 & 103.4 & 103.7 & 101.7 & 97.4 & 98.9 & 100.3 & 106.1 & 105.4 & 110.7 \\
\hline Ireland & 48.5 & 37.8 & 35.5 & 32.1 & 30.9 & 29.6 & 27.4 & 24.8 & 25.0 & 44.0 \\
\hline Italy & 113.7 & 109.2 & 108.8 & 105.7 & 104.4 & 103.9 & 105.9 & 106.6 & 103.6 & 106.3 \\
\hline Luxembourg & 6.4 & 6.2 & 6.3 & 6.3 & 6.1 & 6.3 & 6.1 & 6.7 & 6.7 & 13.6 \\
\hline Netherlands & 61.1 & 53.8 & 50.7 & 50.5 & 52.0 & 52.4 & 51.8 & 47.4 & 45.3 & 58.2 \\
\hline Portugal & 49.6 & 48.5 & 51.2 & 53.8 & 55.9 & 57.6 & 62.8 & 63.9 & 68.3 & 71.6 \\
\hline Spain & 62.3 & 59.3 & 55.6 & 52.5 & 48.7 & 46.2 & 43.0 & 39.6 & 36.1 & 39.8 \\
\hline
\end{tabular}

Source: European Commission, European Economy. Statistical Annex 2011

Another result of the low prevailing interest rates was to fuel asset bubbles and the growth of speculative banking practices. But surprisingly, the impact on prices was relatively mute. No country actually breached the target, when averaged over the decade. Nonetheless, some countries were persistently higher than the three lowest and that difference, although no more than 1-1.5 per cent a year led to a cumulative gap in price levels of almost twenty per cent, and that inflationary gap was measured against some of the most competitive countries in Europe. As the competitiveness of Greece, Spain and Portugal was gradually eroded, so their economic growth slowed and the capacity for workcreation was much reduced. The promise of convergence - high growth paid for by higher inflation - was turning into an ash of just higher inflation. If European demand were to slow, these weaknesses would be cruelly exposed.

Table 3: Average HICP Inflation Rate over the first decade of the Euro

\begin{tabular}{|l|l|l|l|l|l|l|}
\hline Lowest 3 & Áustria & Bélgica & Finlândia & França & Alemanha & Irlanda \\
\hline 1.77 & 1.98 & 2.18 & 1.76 & 1.91 & 1.68 & 1.96 \\
\hline Itália & Grécia & Luxemburgo & Holanda & Portugal & Espanha & \\
\hline 2.29 & 3.36 & 2.78 & 1.88 & 2.37 & 2.85 & \\
\hline
\end{tabular}

Source: CBS Webmagazine 10.1.2012 


\section{The Crisis}

Few economists had anticipated the financial crisis that swept through the world economy in 2008. The signs of asset bubbles had been apparent much earlier. The ratio of real estate prices to earnings in parts of the USA, in some Mediterranean countries (as well as in Ireland and the Netherlands) had already reached levels that would prove difficult to sustain, but an adjustment need not necessarily precipitate a collapse. Ironically, it was the fact that such adjustment was underway that precipitated the crisis as people in the USA defaulted on their housing loans. This would impact directly on those financial agencies directly involved in the housing market, and it did. The Lehman Brothers, Freddie Mac and Freddie May were soon all in financial difficulties and Lehman Brothers filed for bankruptcy on $15^{\text {th }}$ September 2008. What tilted a sectoral crisis into a truly global one was the at that Lehman Brothers had sold on the ownership of some of its mortgage assets to other banks, but in forms that made it difficult to assess the risk involved. Other banks held these poisoned assets and noone knew which banks they were and what was the degree of the exposure. Inter-bank lending, which served to lubricate the world economy, contracted virtually overnight and the impact of the resulting 'credit crunch' reverberated through the developed economies of North America and Western Europe (EICHENGREEN et al, 2009). As far as the Eurozone was concerned, attention rapidly focused on four countries, rather ungraciously known as the PIIGS - Portugal, Ireland, Italy, Greece and Spain.

Table 4. Government Debt and Deficit Data for "PIIGS" countries

\begin{tabular}{|l|l|l|l|l|l|}
\hline \multicolumn{7}{|l|}{} & Portugal & Ireland & Italy & Greece & Spain \\
\hline Government deficit & -3.5 & -7.3 & -2.7 & -9.8 & -4.2 \\
\hline 2008 & -10.1 & -14.3 & -5.4 & -15.4 & -11.1 \\
\hline 2009 & -9.1 & -32.4 & -4.6 & -10.5 & -9.2 \\
\hline 2010 & -5.9 & -10.5 & -4.0 & -9.5 & -6.3 \\
\hline 2011 & 71.6 & 44.4 & 106.3 & 110.7 & 39.8 \\
\hline Government debt & 83.0 & 65.6 & 116.1 & 127.1 & 53.3 \\
\hline 2008 & 93.0 & 96.2 & 119.0 & 142.8 & 60.1 \\
\hline 2009 & 101.7 & 112.0 & 120.3 & 157.7 & 68.1 \\
\hline 2010 &
\end{tabular}

Source: European Commission, European Economy. Statistical Annex 2012 


\section{Richard Griffiths}

Let us start with Ireland. Ireland had been almost a show-case country for the European Union. It was the "Celtic Tiger" that, with financial support from the European Union, had transformed itself from a lesser developed part of the Continent into one that had overtaken the UK in terms of per capita national income. All of its financial indicators conformed to the targets of the Stability and Growth Pact. But none of this reflected the growing instability of the private sector. Banks had overextended themselves by borrowing cheaply on international markets and fuelling a "property bubble' of impressive dimensions. Property prices had already begun to slide in 2007 , but collapsed as the credit crisis struck the country. To stem a possible run on overextended banks the government first guaranteed all bank deposits and, a year later, effectively nationalized the banks' bad debts. This was against the backdrop of a gathering recession that eroding government income and a programme of fiscal restraint. As the government's borrowing requirement ballooned and the level of sovereign debt soared, the credit lines began understandably to tighten (LANE, 2011). In November 2010, the country accepted a 'bail-out' package of $€ 67.5$ billion supplied by the IMF and the European Union (with three non-euro countries - UK, Denmark and Sweden - contributing individually) on condition that the government enact further measures to bring government spending under control.

For the purpose of this article, Italy, Portugal and Spain fall almost into the same category, though there are marked differences between them. They are all countries whose competitive positions were eroded during the years of the build-up to, and adoption of, the euro when the impact of price and inflation differentials could not be rectified by currency depreciation. Nailed to a $21^{\text {st }}$ century version of the gold-standard, economic equilibrium depended increasingly on domestic deflation, to reduce prices, or on economic reform, to increase competitiveness. When a country does neither, the foundations of economic growth become eroded and they become increasing vulnerable to the impact of cyclical downturns. In the case of Spain and Portugal, the situation was aggravated by a speculative property boom, similar to that which had characterized developments in Ireland. In these countries, too, when the bubble burst, the subsequent contraction of the construction sector led the slide into recession with rising unemployment and a burgeoning fiscal deficit. In Spain 
the impact was cushioned by the relatively low level of government debt but for Portugal the twin demands of rolling over debt and funding the current deficit stretched the confidence in the government's ability to pay (BLUNDELLWIGNALL; SLOVIK, 2011). In May 2011 the European Union the ECB and the IMF (jointly known as the Troika) contributed to a Portuguese 'bail-out' of $€ 78$ billion, conditional on new austerity and privatization measures. Italy has been caught in the back-wash of these developments. Although it has a relatively high level of debt, its repayment schedule is not tight and much of the debt is held domestically. Moreover, its current deficit levels are not out of line with those elsewhere in Western Europe. With markets jittery, there were doubts over the ability of Italy's ability to sustain these debt levels given the erosion of its competitiveness and growth potential and concern over the inability of the government to cut expenditure and introduce reforms. As the cost of borrowing edged ever higher, the Berlusconi government stepped down and was replaced by an emergency technocratic government deemed capable of enacting the necessary reforms.

We can now turn to Greece. The country entered the Euro two years after the start because the European Commission and member states were uncertain whether it could maintain the necessary discipline. They should have stayed skeptical, but as the Greek government managed to manipulate its budget deficit to a record low of 2.7 per cent in 2000 , the doubts were laid aside and Euro membership was granted. The latest revised data for the year 2000 shows a deficit a full one percentage point higher. Whatever the true figure, it was the best result Greece managed to achieve since thereafter the deficits annually crept ever upwards but initially, because the economy was still growing strongly on the back of cheap credit, not so the level of debt. Although successive Greek budgets became more profligate, from 2005 the debt levels did begin to respond. In that year, the Commission revealed systematic underreporting of deficits by the Greek government and it started proceedings against it. These persisted until 2007, but stopped short of applying sanctions (EUROPEAN COMISSION, 2005). Meanwhile, in 2006 the Greek government attempted a new approach which had to succeeded would have slashed the size of the deficit and weight of debt by a quarter. In September 2006 it suggested that the national income be raised by 25 per cent to include the (unreported) 


\section{Richard Griffiths}

'black economy'. This was rejected by Eurostat officials but they did allow an upward revision of 9.7 per cent.

The recession hit Greece hard. Competitiveness had been deteriorating and its shipping and tourism industries were particularly vulnerable to a cyclical downturn. The Greek budget forecast for 2009 was originally for a deficit of 3.7 per cent, down from the 5 per cent reported for 2008. By October of that year the two figures were revised upwards to 12.5 per cent and 7.7 per cent respectively. The European Commission's (2010) judgement was damning. While accepting that Greek statistical recording and reporting was a mess, it also suggested that figures had been deliberately manipulated for political ends. The implications were that Greek financial reporting was uncontrolled and uncontrollable. Several months later Der Spiegel (2010) revealed that Goldman Sachs had connived in the underreporting of government debt by arranging currency swaps at fictitious rates that concealed the true level of government indebtedness.

The spiraling levels of Greek indebtedness undermined any remaining confidence of markets in the ability of the government ever to redeem them. Interest rates on new Greek borrowing shot skywards and in April 2010 the government applied for a loan of $€ 45$ billion to cover its borrowing commitments for the rest of the year. A month later, after imposing savage budget cuts, and provoking a bitter public reaction, it received a bailout of $€ 110$ billion from the IMF, the ECB and the EU. By now, the impact of the recession, reinforced by the government's deflationary policy, were further undermining tax receipts. The Troika responded in October 2011 by offering a second bail-out worth $€ 130$ billion, on condition that Greece produce a convincing and effective austerity and reform programme. At the same time, it pressured private holders of Greek debt voluntarily accept a debt restructuring package involving losses of up to 70 per cent on the face value of their loans, and at the same time converting them to new longer-term loans at favourable interest. It was an all-or-nothing offer, and succeeded in reducing the level of Greek debt by $€ 105$ billion. A new technocratic government, meanwhile, committed itself to bringing the level of sovereign debt back down to 120 per cent by 2020 (most recently revised to 117 per cent) - the level at which it had stood when the crisis began. 


\section{Lessons from the Eurocrisis}

The above description of the crisis is a tidy version of events. Reality was rather different. The first problem was that Article 125 of the Maastricht treaty specifically ruled out the option of a "bail-out" for countries with public debt problems. This position designed to eliminate the danger of what economist call "moral hazard" whereby relief measures apparently condone and reinforce the tendency towards the deviant behaviour that had caused the problem in the first place. Thus as the banking crisis was undermining the stability of the financial sector in various Eurozone countries, and when markets needed reassurance, the ministers of the 27 member states had to agree the basis for any intervention. Neither the framework nor the means for intervention were in place before hand. When the means were in place, they were scarcely of the magnitude to reassure the markets. It did not take a Nobel-prize economist to figure out that the size of the 'bail-out' funds would be insufficient to resolve multiple concurrent crises. Moreover, as the disbursement of the funds was made conditional upon remedial measures being taken by the recipient, the entire operation doubled the causes of uncertainty, without ever resolving the essential question - would it ever be enough?

At present, in March 2012, the European Union has agreed to strengthen its financial governance. It increased the possibility of implementing an "excessive deficit procedure" and introduced a "reverse qualified majority voting procedure" (whereby a judgement could only be overturned by a majority against) to enable the imposition of sanctions that could amount to 0.5 per cent of GDP. A separate intergovernmental treaty would require governments to limit deficits to 0.5 per cent of GDP (one per cent if countries had a debt level of less than 60 per cent), but with escape clauses for special circumstances. These limits should be introduced into national law. Surveillance and cooperation measures were also strengthened. At the same time, the financial instruments were strengthened. In May 2010, the EU finance ministers had created a temporary funding arrangement - the European Financial Stability Facility (EFSF) with a capital commitment of $€ 780$ billion and a lending capacity of $€ 440$ billion. In December 2010, they agreed to the creation of a permanent European Stability Mechanism (ESM) with a lending capacity of $€ 500$ billion to take over from the EFSF when it elapses in July 2013. Since the EFSF has already lent $€ 192$ billion, the open question at time of writing is 


\section{Richard Griffiths}

whether to treat the ESM additional funding, raising the total to $€ 692$ billion, or not. Whatever, they decide, it will never be enough if a cataclysm does occur.

For now, the crisis has apparently subsided. Let us now briefly examine the cost and then, speculate about the future. When the crisis broke, I was in favour of the European Union maintaining its 'no bail out' stance, partly because of the moral hazard argument and partly because there was a readymade alternative in the form of the IMF. All the EU member states are individually members of the IMF and the IMF has both the mandate and the means to intervene. One argument is that the IMF might not have had the funds, but that could have been resolved by raising its capital. This need not have been difficult since the BRIC countries had wanted to do this for some time (increasing their voting power in the process) and the EU states could have contributed as well. With this resolved, the IMF could have gone into countries, bullied their governments, making itself thoroughly resented, and then left. Instead, the EU put itself into the middle of this process, despite the fact that it was not equipped for the task and that it was not a unitary actor. As a result the EU has complicated the rescue plans and heaped disapproval and resentment upon itself. This would also have been true of the IMF, but the IMF is not trying to build "an ever closer union" as the EU is pledged to do. As distrust of Brussels institutions is rising, the EU's active involvement in various austerity programmes will damage its chances of securing referenda for any future treaty changes it requires, and moving the reform agenda outside the usual democratic circuits will only increase public disenchantment. The EU may still weather the crisis, but it could be paying the political price long after the monetary costs have been absorbed and forgotten.

But has it solved the crisis? At the moment, the markets are calm, but markets are hardly a trustworthy barometer. Despite their elevation in globalisation literature to almost omnipotent and omniscient status, markets have not performed well. In currency markets, they have presided over wild swings (both overshooting and undershooting) in exchange rates and they have long ignored blatant signs of difficulties in the capacity of debt service by certain states. They are now supposed to have been reassured by the new firmness of the EU approach, a firmness which at its first test was to give a waiver from its solemn obligations to Spain. Spain had overshot its deficit in 
2011 (8.5 per cent instead of 6.0 per cent) and was given a revised target for 2012 (5.8 per cent instead of 4.4 per cent). It is good to build exceptions into legislation, but it is not good politics to begin with them. The Dutch, hitherto one of the 'best boys' in the class, has a minority government coalition in trouble over meeting the EU's criterion, and an opposition and the influential Central Planning Bureau, opposed. It may become a second country missing its obligations. And if it is not the Netherlands, there are several candidates to be next in line for special treatment.

A further problem lies in the effectiveness of the various austerity programmes. Piling deflation on economies that are already contracting usually serves to exacerbate the downward trend and could even increase the level of deficit or debt, expressed in relation to a lower GDP. The apparent immunity of deficits to the medicine prescribed may well again lead investors to question the creditworthiness of nation states, but not only them. Several countries that had experiences a credit boom in the years before the crisis also experienced inflated asset prices, which have not yet fully adjusted to the new realities. In the absence of a reappearance of sustained growth, these assets are often still lurking at inflated values on bank balance sheets. The next market attack may not be one of confidence in governments, but of confidence in banks. If, for example, housing prices do not recover in Spain, a run on Spanish banks could still occur, confronting the government with the alternatives of financial meltdown or nationalization of bank assets. This could precipitate another 'bailout', but this time on a much larger scale than any than have gone before (MCRAE, 2012). But even if we ride out these problems, we still have Greece. It surely stretches credulity to believe that a country where the tax system is inefficient and the population resentful, where the tax evader is a hero and the honest man a fool, is going to reduce its sovereign debt level to 120 per cent by 2020 and run a balanced budget every year, for the next ten-twenty years thereafter, until its level of debt reaches 60 per cent.

A final consideration lies in the fact that even if the $E U$ resolves the debt/deficit issues, we have done nothing to deal with the gap in competitiveness that has emerged. It is very difficult to press a 20 percent price differential out of the system, especially without the option of devaluation. The 'gold bloc' countries attempted this in the 1930s and failed (EICHENGREEN; IRWIN, 2010). My guess is that the Mediterranean countries, trapped within 


\section{Richard Griffiths}

the Euro and without the option of domestic protection, may find themselves left with a sound fiscal base but with a stagnant economy. The alternative of leaving the euro and adopting a new (depreciating) currency is also not an attractive option. Even should the Euro survive, for them there is no happy ending inside or outside the bloc.

\section{Conclusion}

In May 2008 The European Commission celebrated the tenth anniversary of the start of the Eurozone (not the issue of the currency) with the publication of a commemorative volume. Writing its forward, the Commissioner for Economic and Monetary Affairs trumpeted:

"A full decade after Europe's leaders took the decision to launch the euro, we have good reason to be proud of our single currency. The economic and monetary union and the euro are a major success. For its member countries, EMU has anchored macro-economic stability, increased cross border trade, financial integration and investment. For the EU as a whole, the euro is a keystone for further economic integration and a potent symbol of our growing political unity. And for the world, the euro is a major new pillar in the international monetary system and a pole of stability for the global economy."(EUROPEAN COMISSION, 2008, iii)

It is sad to reflect, now, that the design was faulty, the implementation flawed, the management lax, the crisis mishandled and that the future still remains uncertain. To push forward towards even more 'European' solutions, to see the crisis as an opportunity, would at this moment be a mistake. The public is not ready for such a move, and are unlikely to forgive (yet another) attempt to do things above their heads, if not behind their backs. For the moment, it would be a considerable achievement to hold the stability of the currency area. The Euro is easily salvageable, if not necessarily with its current membership. Once matters have settled, there will be the time to find structural solutions and to continue on the road of what, for all its shortcomings, has been one of the greatest achievements of post-war European history. And when we offer lessons to others, it may be with a little more modesty and humility that has often been the case in the past. 


\section{REFERENCES}

BOS, F. (2008) Use of National Accounts. History, Standardisation and Application in the Netherland, MPRA Paper 9387, http://mpra.ub.unimuenchen.de/9387/1/MPRA_paper_9387.pdf

BLUNDELL-WIGNALL , A. and P Slovik (2011) "A market perspective on the european sovereign debt and banking crisis". OECD Journal: Financial Market Trends, 2, 1-28

BUITER, W., G. Corsetti and N. Roubini (1993) "Excessive deficits. Sense and nonsense in the Treaty of Maastricht" Economic Policy, 8, 16, 57-100.

COLLINGON, S. (2004) "The End of the Stability and Growth Pact?" International Economics and Economic Policy, 1, 1, 15-19.

DER SPIEGEL, Online International http://www.spiegel.de/international/europe/0,1518,676634,00.html

EICHENGREEN, B.; A. Mody, M. Nedeljkovic, and Lucio Sarno (2009) How the Subprime Crisis Went Global: Evidence from Bank Credit Default Swap Spreads, NBER Working Paper No. 14904.

EICHENGREEN, B and D. A. Irwin (2010) "The Slide to Protectionism in the Great Depression: Who Succumbed and Why?" Journal of Economic History, 70, 04, 871-897.

EHRMANN, M; M. FRATZSCHER, R. S. GÜRKAYNAK and E. T. SWANSON (2011) "Convergence and Anchoring of Yield Curves in the Euro Area", Review of Economics and Statistics, 93, 1, 350-364.

EUROPEAN POLICY CENTRE (2012) The Maastricht Treaty - 20 years later, Event Report dd 16.02.2102

EUROSTAT (2004) Report by Eurostat on the Revision of the Greek Government Deficits and Debt Figures, 4.11.2004

EUROPEAN COMMISSION (various), European Economy, Brussels

EUROPEAN COMMISSION (2008)TheEMU@10. Successes and Challenges after ten years of Economic and Monetary Union, Brussels.

EUROPEAN COMMISSION (2010), Report on Greek government deficit and debt statistics, 8.1.2010

FINGLETON, B (1999) "Estimates of time to economic convergence: an analysis of regions of the European Union" International Regional Science Review, 22, $1,5-34$.

FISCHER, J.; L JONGUN and M. LARCH (2006) 101 Proposals to reform the stability and Growth pact. Why so many? European economy. Economic papers. No 267, Brussels

GARRETT, G. (1993)“The Politics of Maastricht" Economy and Politics, 5, 2, 105-123

ISSING, O. (2008) The Birth of the Euro, Cambridge.

JORDAN-WAGNER, J. (1994) "A Historical Analysis of ERM realignments" Essays in Economic and Business History, 12, 31-47.

LANE, P. (2011) The Irish Crisis, CEPR Discussion Paper No. DP8287 


\section{Richard Griffiths}

LEONARDI, R. (1995) Convergence, cohesion and integration in the European Union, New York.

MCRAE, H. "Why Spain is odds-on for a bailout by the end of the year" The Independent, 29.2.2012

SIESTO, V (1987) "Concepts and Methods involved in the Last Revision of Italy's GDP" Labour, 1, 3, 181-200. 


\begin{abstract}
This article examines the European experience with economic and monetary union from three perspectives - the design, the implementation and the management of the euro - before exploring the implications of the current crisis.
\end{abstract}

\title{
KEYWORDS
}

Euro; Crisis; European Union; 